\title{
Impacts of haze in 2002 on social activity and human health in Palangka Raya
}

\author{
Suwido H. Limin ${ }^{1, *}$, Hidenori Takahashi ${ }^{2}$, Aswin Dj UsuP ${ }^{1}$, Hiroshi HaYasaka ${ }^{3}$, Mitsuhiko \\ KAMIYA $^{4}$ and Naoto MURAO ${ }^{3}$ \\ University of Palangka Raya, Palangka Raya, Central Kalimantan 73111, Indonesia \\ ${ }^{2}$ Hokkaido Institute of Hydro-climate, Kita-ku, Sapporo 001-0014, Japan \\ Graduate School of Engineering, Hokkaido University, Kita-ku, Sapporo 060-8628, Japan \\ ${ }^{4}$ Faculty of Engineering, Hokkaido Institute of Technology, Teine-ku, Sapporo 006-8585, Japan \\ *Corresponding author: Suwido H. LIMIN. E-mail: cimtrop_suwido@yahoo.com; suwido@palangkaraya.wasantara.net.id
}

ABSTRACT Dense haze emitted from peatland and forest fires in 1997/98 and 2002 damaged not only the peatland and forests themselves, but also the social activity and human health in many South East Asian countries. Several components of air quality, namely carbon monoxide, sulfur dioxide, nitrogen oxide, nitrogen dioxide, ozone and particulate matter less than $10 \mu \mathrm{m}$ in diameter, were monitored since 2001 by the Environmental Impact Agency of Palangka Raya at three sites in Palangka Raya, Central Kalimantan. This study focused on daily concentrations of carbon monoxide (CO) and particulate matter less than $10 \mu \mathrm{m}$ in diameter $\left(\mathrm{PM}_{10}\right)$ from 2001 to 2004. Clearly, concentrations of $\mathrm{CO}$ and $\mathrm{PM}_{10}$ increased during the dry season of every year. The 8 hour average levels of $\mathrm{CO}$ concentration were higher than $15 \mathrm{ppm}$ for 42 days during the dry season of 2002, an El Nino year. The $\mathrm{MP}_{10}$ values were also very high during the 2002 dry season. The $\mathbf{P M}_{10}$ values were higher than $250 \mathrm{\mu g} \mathrm{m}^{-3}$ for 84 days in 2002. The high levels in air pollutant materials suggest that people living in Palangka Raya were subject to unhealthy conditions for a long time during the dry season in 2002. The rates of solar radiation on the ground $\left(S_{r}\right)$ against extra-terrestrial solar radiation $\left(\mathrm{S}_{0}\right)$ showed a good correlation to the $\mathbf{P M}_{10}$ values with a high coefficient of determination (0.92) during the dry season in 2002. The regression curve was applied to solar radiation on the ground in 1997 . The result shows that the level of $\mathbf{P M}_{10}$ in Palangka Raya was the same in September and October in both years, but high levels of $\mathbf{P M}_{10}$ continued until November of 1997. The 2002 forest fires were responsible for financial losses at the national level. Merpati Nusantara Airline, Mandala Airline and Dirgantara Air Service lost 10.6 billion Rupiah, 2.8 billion
Rupiah and 235 million Rupiah, respectively, while Garuda Indonesia Airline and Bouraq Airline lost 76.8 billion and 954 million Rupiah, respectively. Many schools (kindergartens, basic schools and elementary schools) were closed for one to four weeks. Many very old and very young people became ill and died. The estimated numbers of health cases in Central Kalimantan caused by forest fire are as follows: Death, 29 people; Asthma, 17,270 people; Bronchitis, 3,366 people; and ISPA, 83,772 people. The fires and haze restricted the ability of people to work and 275,660 people were forced to work only occasionally, while 141,714 people stopped working completely for the duration of the forest fires and produce thick smoke.

Key words: peatland, fire, haze, air pollution, human health

\section{INTRODUCTION}

The El Nino event in 1997/98 was the largest one since 1946, and the drought in Kalimantan was also estimated to be one of the most severe of the $20^{\text {th }}$ century (Takahashi et al. 2001). Transportation in Southeast Asia was seriously affected by the low visibility caused by the dense haze emitted from peat/forest fires. The most tragic accident occurred on a flight arriving in Medan Sumatra on September $26^{\text {th }}$, 1997. The aircraft collided into a mountain near the airport owing to the low visibility and the 234 people on board were killed. In several cities, including Jambi, Pontianak and Banjarmasin, visibility at times declined to 20 meters (Potter, 1997). The peat/forest fires also greatly impacted tropical forest ecosystems, not only by burning them, but also by reducing solar radiation and photosynthetic photon flux 
density (PFD). Clearly, smoke from the fires caused the dense haze (Tang et al. 1996; Takahashi et al. 1999).

In 1997 alone, haze caused by air pollutants from fires spread more than 3,200 kilometers, affecting six Southeast Asian countries. In the Malaysian state of Sarawak, air pollution reached one the highest recorded indices at $839 \mu \mathrm{g} \mathrm{m}^{-3}$, which is quite dangerous considering that levels over $301 \mathrm{\mu g} \mathrm{m}^{-3}$ are equal to smoking 80 cigarettes a day. The fires in Southeast Asia put 20 million people at risk of respiratory problems and cost 1,400 million U.S.\$ in healthcare (Shrestha, 2004). Kalimantan was one of biggest sources of haze emission during the peat/forest fires in 1997 (Potter, 1997).

Particles that are small enough to get into the lungs (those less than or equal to $10 \mu \mathrm{m}$ in diameter) can cause numerous health problems and have been linked to illnesses and deaths from heart and lung diseases. 716,000 people living in Central Kalimantan were subject to the serious air pollution in $1997 / 98$, of these residents 29 died, 17,270 had asthma, 3,366 had bronchitis and 83,772 were infected by other respiratory disorders (Widen, 2005).

After the haze problem in 1997/98, the Indonesian government, with the support of the Austrian Energy \& Environment SGP, constructed a network for monitoring air pollution at several cities, including Palangka Raya. Daily values of six components of air pollution (carbon monoxide, sulfur dioxide, nitrogen oxide, ozone and particulate matter less than $10 \mu \mathrm{m}$ in diameter) have been measured in the city area of Palangka Raya since 2001.

The authors have shown that the ground water level in tropical peat swamp forests is a suitable indicator of the level of peat/forest fire damage (Takahashi, 2003). Muraleedharan et al. (2000) studied the chemical components emitted from the combustion of tropical peat sampled in Brunei. According to their results, 185 $\mathrm{g}$ of $\mathrm{CO}_{2}, 37 \mathrm{~g}$ of $\mathrm{CO}$ and $6 \mathrm{~g}$ of $\mathrm{CH}_{4}$ were emitted from combustion of $1 \mathrm{~kg}$ of peat (dry weight).

$\mathrm{CO}$ and $\mathrm{PM}_{10}$ concentrations are the focus of this paper, because they negatively impact human health. The seasonal variations of these two components were analyzed for four years starting in 2001 and compared with the behavior of ground water levels in a tropical peat swamp forest located in same area.

\section{LOCATION AND MESUREMENTS}

The urban area of Palangka Raya City, the capital of Central Kalimantan, is located on the east bank of the Kahayan River. Air pollution of the urban area was monitored at three points: Tjilik Riwut, Tilung and Murjani (Fig.1).

Elements of air pollution monitored were carbon monoxide and particulate matter less than 10 p.m. in diameter. The data were sent to the Air Quality Management System Regional Center where the Pollutant Standard Index (PSI) was calculated every hour. The PSI level, upgraded every hour, was displayed on the notice board in the city center. Carbon monoxide concentration was measured using the non-dispersion cross modulation infrared analysis method (APMA-360, Horiba). The amount of particulate matter less than 10 $\mu \mathrm{m}$ in diameter was measured using the $\beta$-ray absorption method (APDA-361, Horiba).

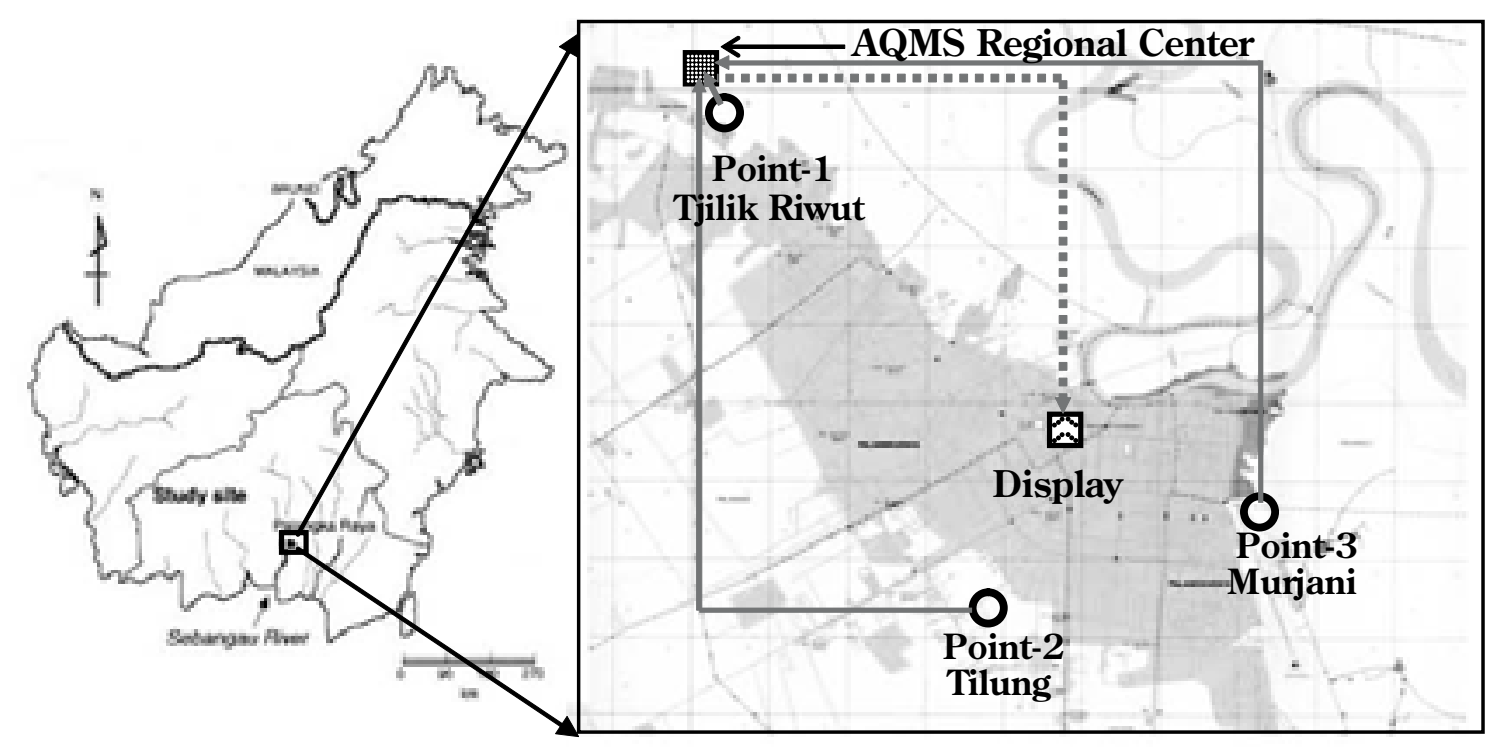

Fig. 1. Locations of study site and air pollution monitoring stations in Palangka Raya. 
Ground water level was measured at the Plot-1b monitoring plot that is in a tropical peat swamp forest in the upper catchment of the River Sabangau. Plot-1b is located about $12 \mathrm{~km}$ south of the city center. Ground water level was measured using a data logger with a pressure sensor (Kadec-Mizu, Kona System and DL/N, STS). Solar radiation on the ground was measured with a pyranometer (PCM-01, PREDE) and a data logger (Kadec-up, Kona System) at the open area near the border of the forest. Rainfall data were obtained from the Palangka Raya Meteorological Observatory near the airport.

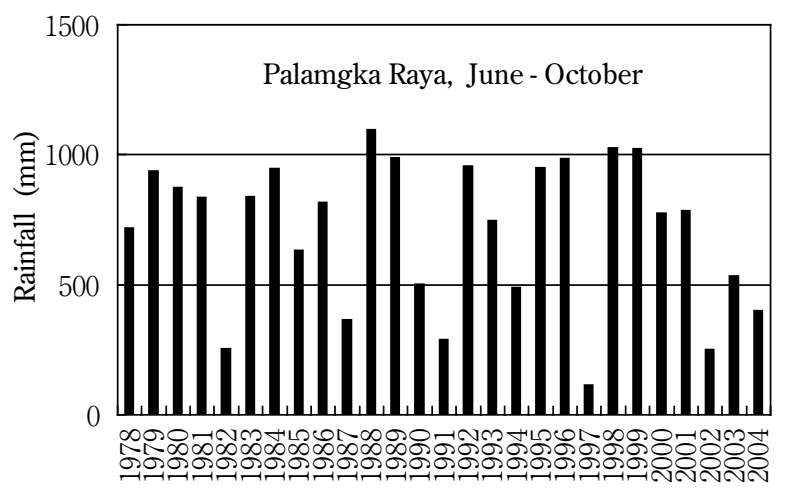

Fig. 2. Total rainfall during the dry season, JuneOctober, in Palangka Raya from 1978 to 2004.

\section{RESULTS AND DISCUSSIONS}

Weather and hydrological conditions of peatland

The 27 year average total annual rainfall in Palangka Raya (from 1978 to 2004) is 2,856 mm. During this period, the maximum was $3,613 \mathrm{~mm}$ (1983) and the minimum 1,841 $\mathrm{mm}$ (2002). Total amount of rainfall during the dry season is an important figure for estimating the damage level of peat/forest fire in tropical peatland (Takahashi, 2001). The total amount of rainfall during the dry season from June to October in Palangka Raya is shown in Fig. 2.

The minimum rainfall during this period was $117 \mathrm{~mm}$ during the dry season in 1997, followed by $255 \mathrm{~mm}$ in 2002. Ground water level at Plot-1b decreased to $100 \mathrm{~cm}$ below the peat surface in 2002, which was lower than it was in 1997 (Fig. 3). Very low ground water levels during the dry seasons in 1997 and 2002 indicate that those years' peat/forest fires in this area were hazardous.

\section{Burned area of peatland in Central Kalimantan}

Extrapolating from the study area burn data (2,491,619 ha burnt in 1997 and 5,180,395 ha in 2002), indicates that 29.3\% of the Mega Rice Project (MRP) area was burnt in 1997 and 5.29\% in 2002 (Table 1 and Fig. 4).

\section{Air pollution in Palangka Raya}

Daily maximum 8 hours average values of $\mathrm{CO}$ concentration in the air from 2001 to 2004 are shown in Fig. 5. Ground water level is also shown on the figure as an index of drought and peat/forest fire events. One

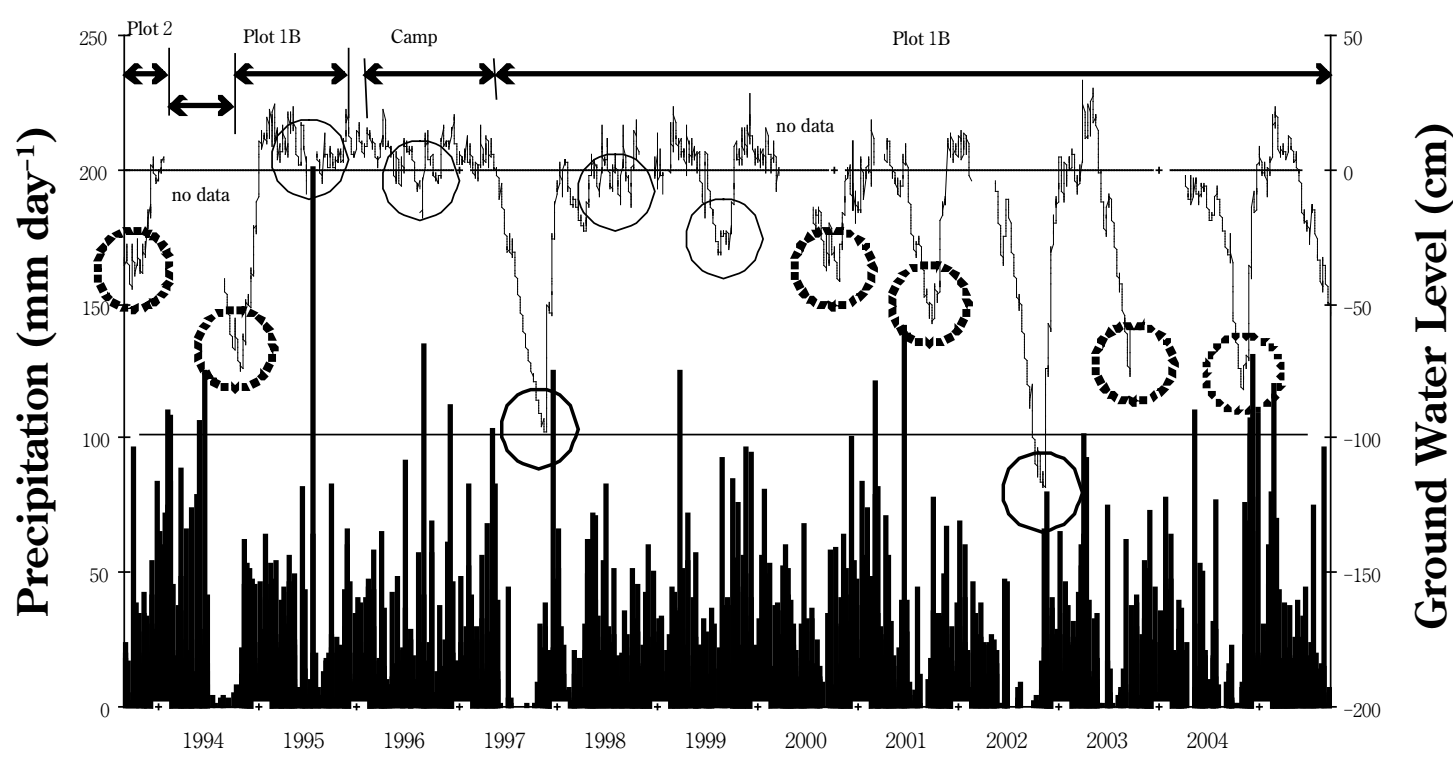

Fig. 3. Long term changes of daily mean ground water level at a peat swam forest in Plot $1 \mathrm{~b}$ and rainfall in Palangka Raya. Bold circle: very dry year with El Niño; dotted circle: medium dry year; thin circle: wet year. 
Table 1. Area of peatland burned in 1997 and 2002.

\begin{tabular}{lccc}
\hline \multicolumn{1}{c}{ Location } & Total Peatland Area (ha) & \multicolumn{2}{c}{ Area of Fire Damaged Peatland } \\
\cline { 2 - 4 } & & $1997^{1)}$ & $2002^{2)}$ \\
\hline Block C of MRP & 383,800 & $184,564(48.1 \%)$ & $79,608(14.0 \%)$ \\
Block B of MRP & 161,480 & - & $30,519(18.9 \%)$ \\
Entire MRP & 988,568 & $474,009(48.0 \%)$ & - \\
Study Area & & & - \\
a. 2.5 million hectares & $2,491,619$ & $729,500(29.3 \%)$ & $246,742(5.29 \%)$ \\
b. 5.2 million hectares & $5,180,395$ & - &
\end{tabular}

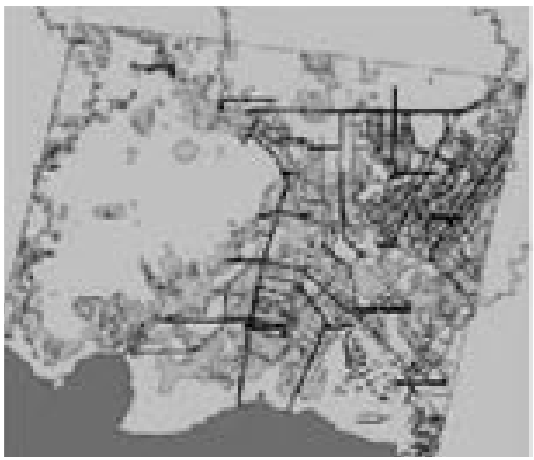

Burnt scars 1997 (yellow)

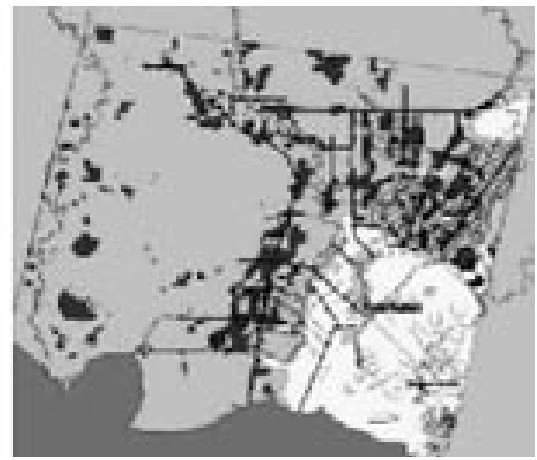

Burnt scars 2002 (red)

(Source: Siegert and Bechteler, 2003)

Figure 4. Burnt scars of forest and peatland in mega rice project (MRP) and surrounding.

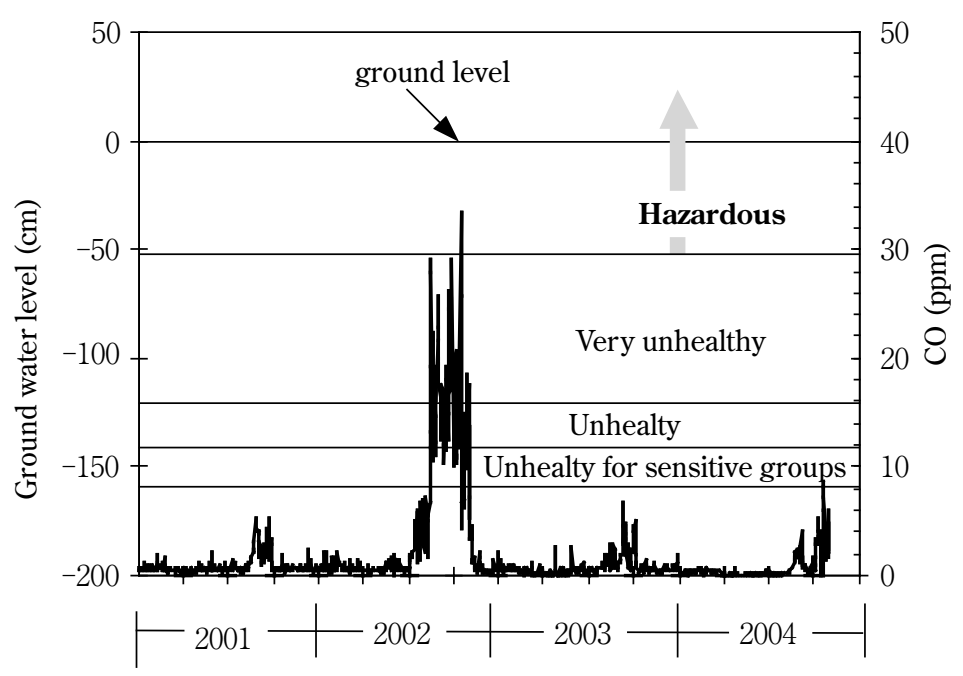

Fig. 5. CO values in Palangka Raya and the ground water levels of a forest in Plot $1 \mathrm{~b}$. abnormal value in the data set of $\mathrm{CO}$ concentration was found and deleted from the data set. CO concentration clearly increased with corresponding changes in ground water level during the dry season in each year and the concentration in 2002 was very high. The U.S. Environmental Protection Agency proposed a new index for categorizing air pollution: PSI, Pollution Standard Index (Environmental Protection Agency, 1998). The definition, descriptors and index values of PSI for CO and $\mathrm{PM}_{10}$ are shown in Tables 2 and 3. The PSI of CO in Palangka Raya showed unhealthy conditions for sensitive groups or all people for 77 days in 2002. Of those, 42 days were very unhealthy conditions and one day was a very hazardous day with $\mathrm{CO}$ concentrations higher than $30 \mathrm{ppm}$ (Table 4).

Diurnal mean $\mathrm{PM}_{10}$ values for air and ground water level in a forest from 2001 to 2004 are shown in Fig. 6. The figure shows the amount of $\mathrm{PM}_{10}$ in the air also increased with lower ground water levels during the dry season of each year. Therefore the particulate matter was emitted from peat fires. The $\mathrm{PM}_{10}$ values reached unhealthy levels in every dry season. In 2002 especially, air pollutant levels were high. In this year, the PSI of $\mathrm{PM}_{10}$ was in the unhealthy level for sensitive groups for 92 days, in the very unhealthy level for normal people for 79 days, in the hazardous level for 
Table 2. Breakpoints for $\mathrm{PM}_{10}$ and CO Sub-indices (Environmental Protection Agency, 1998).

\begin{tabular}{ccc}
\hline PSI values & $\begin{array}{c}\mathrm{PM}_{10}, 24-\mathrm{hr} \\
\left(\mu \mathrm{g} / \mathrm{m}^{3}\right)\end{array}$ & $\begin{array}{c}\mathrm{CO}, 8-\mathrm{hr} \\
(\mathrm{ppm})\end{array}$ \\
\hline 50 & 50 & 4 \\
100 & 150 & 9 \\
150 & 250 & 12 \\
200 & 350 & 15 \\
300 & 420 & 30 \\
400 & 500 & 40 \\
500 & 600 & 50 \\
\hline
\end{tabular}

Table 3. Pollutant Standard Index, PSI (Environmental Protection Agency, 1998).

\begin{tabular}{|c|c|c|}
\hline $\begin{array}{c}\text { Index } \\
\text { Values }\end{array}$ & Descriptor & Purpose \\
\hline $0-50$ & Good & Convey positive message about air quality \\
\hline $51-100$ & Moderate & $\begin{array}{l}\text { Convey message that daily air quality is acceptable from public health perspective, } \\
\text { but every day in this range could result in potential for chronic health effects; and } \\
\text { for } \mathrm{O}_{3} \text {, convey a limited health notice for extremely sensitive individuals. }\end{array}$ \\
\hline $101-150$ & $\begin{array}{l}\text { Unhealthy for } \\
\text { Sensitive Groups }\end{array}$ & Health message for members of sensitive groups. \\
\hline $151-200$ & Unhealthy & $\begin{array}{l}\text { Health advisory of more serious effects for sensitive groups and notice of possible } \\
\text { effects for general population when appropriate. }\end{array}$ \\
\hline $201-300$ & Very Unhealthy & Health alert of more serious effects for sensitive groups and the general population. \\
\hline $301-500$ & Hazardous & Health warnings of emergency conditions. \\
\hline
\end{tabular}

Table 4. PSI in Palangka Raya from 2001 to 2004 (*defined in this paper).

\begin{tabular}{|c|c|c|c|c|c|c|c|c|c|}
\hline \multirow{2}{*}{$\begin{array}{c}\text { Index } \\
\text { Values }\end{array}$} & \multirow{2}{*}{ Descriptor } & \multicolumn{4}{|c|}{$\mathrm{CO}$} & \multicolumn{4}{|c|}{$\mathrm{PM}_{10}$} \\
\hline & & 2001 & 2002 & 2003 & 2004 & 2001 & 2002 & 2003 & 2004 \\
\hline$>101$ & $\begin{array}{l}\text { Unhealthy } \\
\text { for Sensitive } \\
\text { Groups }\end{array}$ & 0 & 77 & 0 & 0 & 23 & 92 & 16 & 33 \\
\hline$>151$ & Unhealthy & 0 & 64 & 0 & 0 & 2 & 84 & 7 & 15 \\
\hline$>201$ & $\begin{array}{l}\text { Very } \\
\text { Unhealthy }\end{array}$ & 0 & 42 & 0 & 0 & 0 & 79 & 1 & 6 \\
\hline$>301$ & Hazardous & 0 & 1 & 0 & 0 & 0 & 72 & 0 & 3 \\
\hline$>500$ & $\begin{array}{l}\text { Seriously } \\
\text { hazardous* }\end{array}$ & 0 & 0 & 0 & 0 & 0 & 61 & 0 & 2 \\
\hline
\end{tabular}




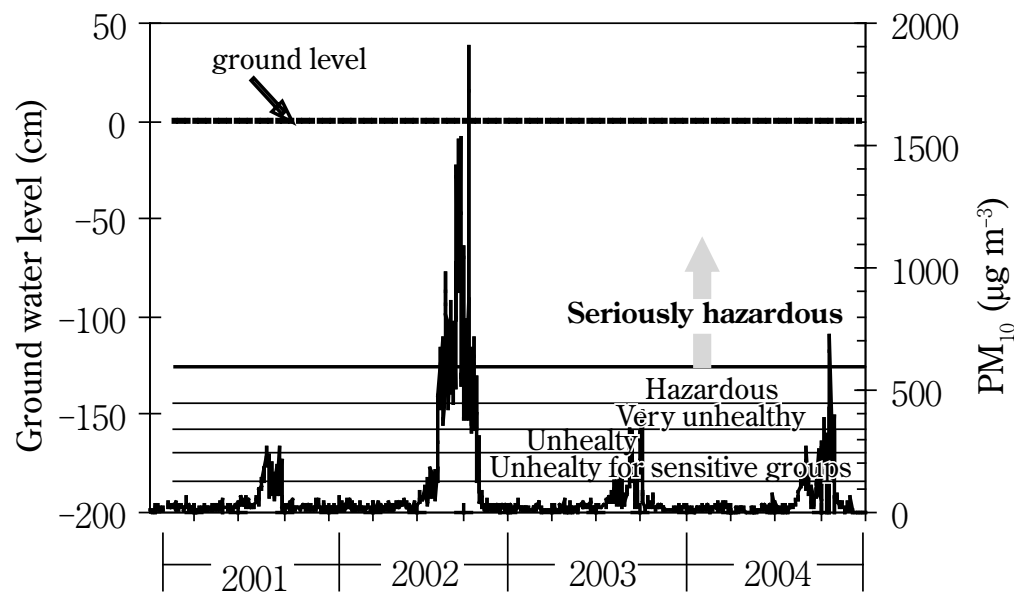

Fig. 6. $\mathrm{PM}_{10}$ values in Palangka Raya and the ground water level in a forest at Plot $\mathbf{1 b}$.

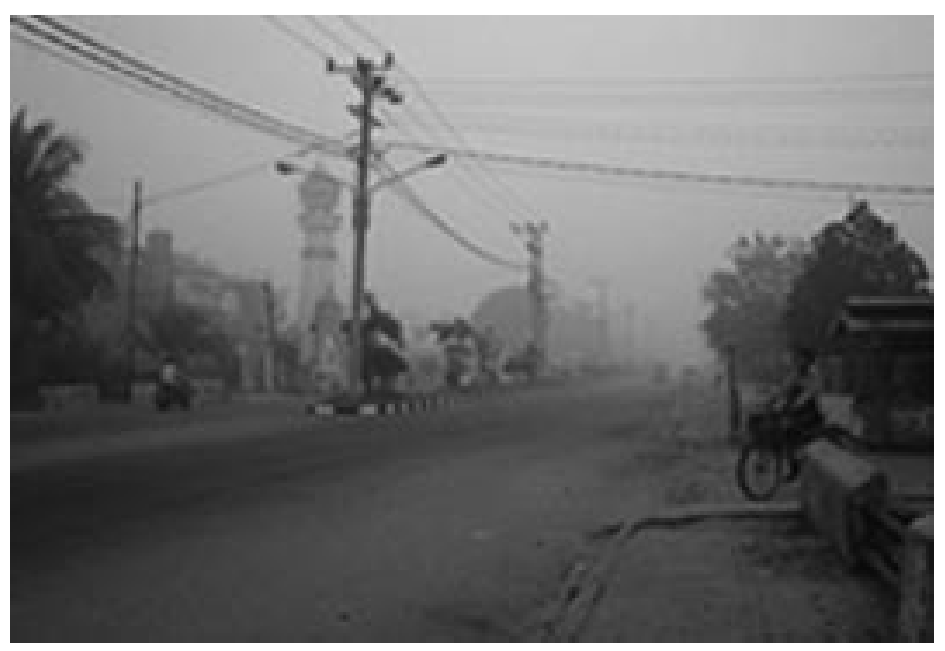

Fig. 7. Low visibility in the Palangka Raya area because of dense haze on September $23^{\text {rd }}, 2002$.
72 days and once it was in the seriously hazardous level. It was amazing that $\mathrm{PM}_{10}$ values were higher than $600 \mu \mathrm{g}$ $\mathrm{m}^{-3}$ for 61 days in $2002 . \mathrm{PM}_{10}$ values higher than $600 \mu \mathrm{g} \mathrm{m}^{-3}$ are above the most hazardous PSI category proposed by the U.S. Environmental Protection Agency. Such extremely high $\mathrm{PM}_{10}$ values are categorized "seriously hazardous". A picture of a street in Palangka Raya taken on September $23^{\text {rd }}$, 2002 shows the low visibility due to the haze (Fig. 7). The $\mathrm{PM}_{10}$ value on that day was $1,523 \mu \mathrm{g} \mathrm{m}^{-3}$, putting it in the seriously hazardous category. A very high particulate matter value of 1,890 $\mu \mathrm{g} \mathrm{m}^{-3}$ was also observed in Pontianak on September $22^{\text {nd }}, 1997$ (Potter, 1997).

$\mathbf{P M}_{10}$ values and reduction of solar radiation on the ground

The ratios of solar radiation on the ground to extra-terrestrial radiation (Sr/S0) were calculated for days without rainfall and with $\mathrm{PM}_{10}$ values higher than $50 \mu \mathrm{g} \mathrm{m}^{-3}$. The $\mathrm{S}_{\mathrm{r}} / \mathrm{S}_{0}$ values have been correlated to $\mathrm{PM}_{10}$ values with a high determination coefficient of 0.92 (Fig. 8). The correlation equation, obtained from the relation between $\mathrm{PM}_{10}$ and $\mathrm{S}_{\mathrm{r}} / \mathrm{S}_{0}$ ratios in 2002 , was applied to the data of $\mathrm{S}_{\mathrm{r}} / \mathrm{S}_{0}$ ratios in 1997 to estimate the $\mathrm{PM}_{10}$ values in 1997

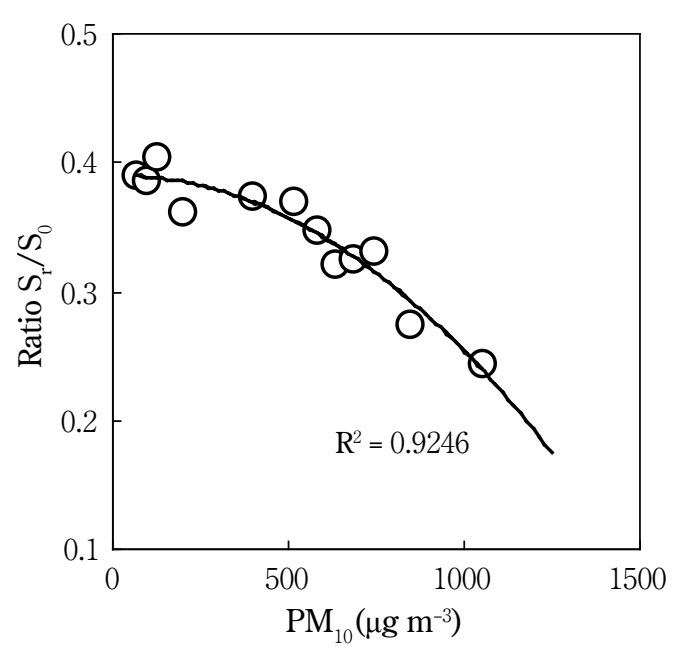

Fig. 8. Relationship between $\mathrm{S}_{\mathrm{r}} / \mathrm{S}_{0}$ and $\mathbf{P} \mathrm{M}_{10}$ values in 2002 .

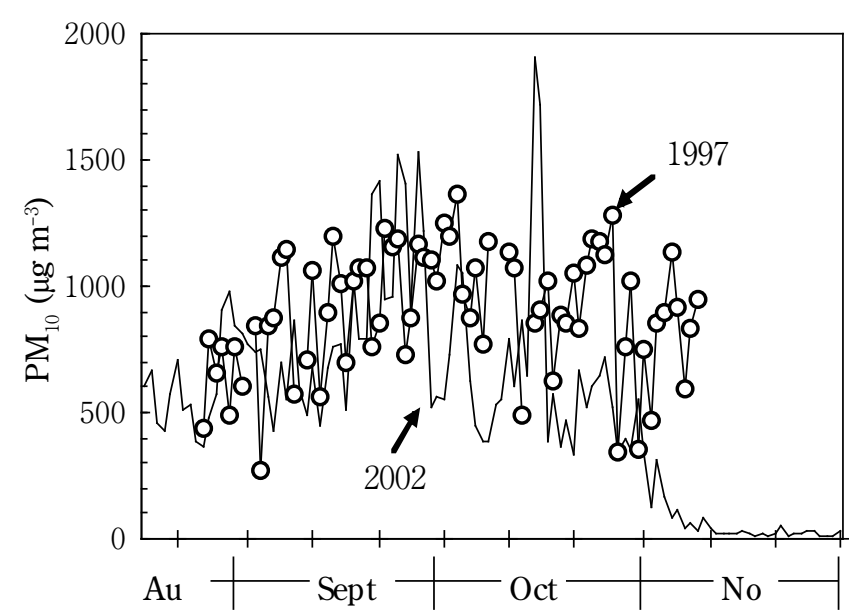

Fig. 9. Seasonal variations of $P M_{10}$ values in 1997 and 2002. 
(Fig. 9). From Fig. 9, it can be determined that the $\mathrm{PM}_{10}$ values in 1997 were almost at the same level as 2002 until the middle of October. After October the $\mathrm{PM}_{10}$ values in 2002 declined; however, in 1997 they remained high until November $9^{\text {th }}$.

\section{Socio-economics and health}

During the forest fires in 2002 that lasted for 4 months, Central Kalimantan, especially the area surrounding Palangka Raya, was covered by thick smoke almost every day, negatively impacting the social-economy and public health. Based on the data of Meneg (1998b), the national financial losses as a result of forest fires in 2002 were:

A. Transportation:

- Dirgantara Air Service (DAS) Rp. 234,713,000

- Merpati Nusantara Airline

Rp. 10.6 billion

- Mandala Airline

- Garuda Indonesia Airline

Rp. 2.8 billion

Rp. 76.8 billion

- Bouraq Airline

Rp. 954,000,000

(Source: Meneg LH, 1998b)

\section{B. School closures:}

When Central Kalimantan was covered by thick smoke, many schools (kindergartens, basic schools and elementary schools) had to close for one to four weeks. Three of the five airlines listed above, namely Dirgantara Air Service (DAS), Merpati Nusantara Airline and Mandala Airline, have routes to and from Palangka Raya. They lost income, because Palangka Raya airport was totally closed for almost one month and had an irregular time schedule for almost another month. The effect of haze on flights in 2002 was not higher than that in 1997. Rieley and Page (2002) also reported that Palangka Raya airport was closed for almost two months and the economic and social life of Central Kalimantan province came to a virtual standstill (Rieley \& Page, 2002).

Social-economic losses were incurred due to the 275.660 people who reduced their work time and the 141,714 people who stopped working completely (Meneg LH, 1998a).

\section{Health}

Inhaling smoke for several weeks caused people to become ill and some died. Based on Meneg (1998a), the estimation of health problems in Central Kalimantan caused by forest fires is as follows:
- Death: 29 people
- Asthma: 17,270 people
- Bronchitis: 3,366 people
- ISPA: 83,772 people

However, according to UNDAC/OCHA (1998), about 23,000 people suffered respiratory diseases and 11 people died.

\section{CONCLUSION}

After analyzing the $\mathrm{CO}$ and $\mathrm{PM}_{10}$ pollutant data recorded in Palangka Raya for four years, 2001 tropical peat swamp forest ground water level measurements and ground solar data, we can conclude the following:

1. The seasonal changes of $\mathrm{CO}$ and $\mathrm{PM}_{10}$ values were synchronized with the lowering of ground water levels measured in a nearby forest.

2. Air pollution during the dry season in 2002 reached a serious and hazardous level, with very high concentrations of $\mathrm{CO}$ and $\mathrm{PM}_{10}$. The $\mathrm{PM}_{10}$ values were higher than PSI 500 for 61 days, putting them above the U.S. Environmental Protection Agency's "hazardous" category.

3. The $\mathrm{PM}_{10}$ values in 1997 remained high until November $9^{\text {th }}, 1997$.

Based on several reports and information, the economic losses and health problems caused by forest fire in 2002 can be summarized as follows: (1) several airline companies' losses totaled Rp. 19.19 billion (9 million U.S. \$), (2) communities suffered decreased worker productivity since 275,660 people had limited work days and a total of 141,714 people completely stopped working, (3) many schools (kindergartens, basic schools and elementary schools) were closed from one to four weeks, and (4) at least 29 people died and 104,408 people got ill with asthma, bronchitis or ISPA.

ACKNOWLEDGMENTS This study was supported with funds from the JSPS-LIPI Core University Program between Hokkaido University and the Research Center for Biology, Indonesian Institute of Science. The air pollution data were supplied by the Environmental Impact Agency of Palangka Raya. We authors wish to express our thanks to the staff members of this agency, who worked hard to maintain the instruments in suitable condition and to monitor the air pollution in Palangka Raya.

\section{REFERENCES}

Environmental Protection Agency. 1998. Air quality index reporting. Federal Register of USA, 63 (236), 67818-67829.

Meneg, L.H. 1998a. Analisis kebijakan penanggulangan kebakaran hutan dan lahan tahun 1997 (Laporan 
akhir posko kebijakan lingkungan hidup). Jakarta.

Meneg, L.H. 1998b. Kebakaran hutan dan lahan di Indonesia. Dampak, faktor dan evaluasi (Jilid 1). Kantor Menteri Negara Lingkungan Hidup RI. United Nations Developments Programme (UNDP). 210p. Jakarta.

Muraleedharan, T.R., Radojevic, M., Waugh, A. \& Caruana, A. 2000. Emissions from the combustion of peat: an experimental study. Atmospheric Environment, 34: 3033-3035.

Page, S.E., Siegert, F., Rieley, J.O., Boehm, H.-D.V., Jaya, A. \& Limin, S.H. 2002. The amount of carbon released from peat and forest fires in Indonesia during 1997. Nature, 420: 61-65.

Potter, L. 1997. 'Where there's SMOKE there's FIRE' SEARCH Vol. 28, No.10, November/December pp. 307-311.

Rieley, J.O. \& Page, S.E. 2002. Peat and forest fire in Indonesian rainforest released huge amounts of $\mathrm{CO}_{2}$. Press Release on November 2002.

Siegert, F. \& Bechteler, A. 2003. Burnt area assesment in Central Kalimantan for the year 2002. Remote Sensing Solutions GmbH \& GeoBio Center at the Ludwig Maximillians University, Munich. Germany.

Surendra, S. 2004. In 1997 and 1998 dry weather conditions, coinciding with a severe El Niño and land-clearing activities, resulted in the most extensive forest fires on record in Indonesia. Health and haze, UNEP/GRID-Arendal, The Environmental Times, Friday Sep 032004.

Takahashi, H. 1999. Hydrological and meteorological environments of inland peat swamp forest in Central Kalimantan, Indonesia with special reference to the effects of forest fire. Tropics, 9: 17-25. (in Japanese with English abstract)

Takahashi, H., Shimada, S., Bismart, F.I, Usup, Dj.A., Yudha. \& Limin, S.H. 2001. Annual and diurnal changes in ground water table and ground surface in a tropical peat swamp forest. Annual report for Fy. 2000 of the core university program by Hokkaido University and Research Center of Biology, Indonesian Institute of Sciences on "Environmental conservation and land use management of wetland ecosystem in Southeast Asia, 209-214.

Takahashi, H., Usup, Dj.A., Hayasaka, H. \& Limin, S.H. 2003. Estimation of ground water level in a peat swamp forest as an index of peat/forest fire. Proceedings of the International Symposium on land management and biodiversity in Southeast Asia, September 2002, Bali Indonesia, 311-314.
Tang, Y., Kachi, N., Furukawa, A. \& Muhamad, A. 1996. Light reduction by regional haze and its effect on simulated leaf photosynthesis in a tropical forest of Malaysia. Forest Ecology and Management, 89: 205-211.

UNDAC/OCHA. 1998. Indonesia, land, bush and forest fires. Mission report of UNDAC Team, MarchApril 1998.

Widen, K. 2005. Impacts of peatland and forest fires on local communities: ecological, health, economics and cultural perspectives. Tropical Peatlands, 5: 12-17.

Received $12^{\text {th }}$ Feb. 2006

Accepted $4^{\text {th }}$ Dec. 2006 